\title{
Articles
}

\section{Judicial Self-Government in Italy: Merits, Limits and the Reality of an Export Model}

\author{
Simone Benvenuti \& Davide Paris
}

\begin{abstract}
The Italian model of judicial self-government is often presented as a successful example of institutional reform to be copied in young democracies. This paper provides a deeper and multifaceted image of it and takes stock of its performance in securing the independence and the accountability of the judiciary. It first maps the rationale and the actors of judicial self-government in Italy, stressing, in particular, that the Italian model of judicial selfgovernment not only aims at preventing the influence of the judiciary by external powers, but it is also equally concerned by threats to judicial independence coming from within the judiciary. It then provides a longitudinal analysis of the impact of this model of judicial selfgovernment on the values of the independence and the accountability of the judiciary after the establishment of the High Council of the Judiciary in 1958. While acknowledging the crucial role of this body in securing the independence of the judiciary, this article claims that the values of independence and accountability of the judiciary have been achieved only progressively and partially.
\end{abstract}

\footnotetext{
Simone Benvenuti is Senior Researcher at Judicial Studies Institute, Masaryk University, simone.benvenuti@law.muni.cz. Davide Paris is Senior Research Fellow at the Max Planck Institute for Comparative Public Law and International Law in Heidelberg, paris@mpil.de. The article is the result of a common effort: Simone Benvenuti wrote parts C and D; Davide Paris wrote Parts A and B. The research leading to this article has received funding from the European Research Council (ERC) under the European Union's Horizon 2020 research and innovation programme (grant no. 678375-JUDI-ARCH-ERC-2015-STG). Many thanks to Davide Servetti for his valuable comments on a previous version of this paper. The usual disclaimers apply.
} 


\section{A. Introduction: An Italian Export Product}

Opinion n. 403/2006 of the Venice Commission on judicial appointments acknowledges that "a variety of different systems for judicial appointments exist and that there is not a single model that would apply to all countries". ${ }^{1}$ However, when it comes to providing advice to new democracies on how to design the appointment system of judges in order to secure judicial independence, the same opinion formulates a set of recommendations that fully correspond to the Italian High Council of the Judiciary (Consiglio Superiore della Magistratura, hereinafter 'CSM'). According to the Venice Commission, for example, "the direct appointment of judges by the judicial council is clearly a valid model" (§ 17); "a substantial element or a majority of the members of the Judicial Council should be elected by the Judiciary itself", while other members should be elected by Parliament with a qualified majority among persons with appropriate legal qualifications ( $\S 29$ and 32); "judicial council should have a decisive influence on the appointment and promotion of judges and [...] on disciplinary measures against them" (§ 25), and so on. This is nothing else but a description of the CSM.

This opinion is just one of the several examples that testify to a strong preference for the Italian model of judicial self-government ('JSG') by the institutions of the European Union and of the Council of Europe. ${ }^{2}$ No doubt, the CSM is a successful Italian export product. Introduced by the 1948 Italian Constitution as the first of its kind, ${ }^{3}$ it served as a model for the new democratic constitutions of Greece, Portugal, Spain first, and then, under the pressure of the European institutions, for the constitutions of the newly established democracies in Central and Eastern Europe. This paper aims to provide a deeper and multifaceted image of the Italian model of JSG. In drawing attention on some less apparent features yet crucial for its proper understanding - such as the existence of a plurality of governing bodies, the awareness of the multidimensional character of independence and the relevance of accountability issues - it stresses that the goals of the independence and of the accountability of the judiciary have been achieved only progressively and partially and they relate to a complex institutional framework which includes other formal and informal actors besides the CSM.

The analysis proceeds as follows. Section B maps the rationale and the actors of the Italian model of JSG. It pinpoints the understanding of the principles of separation of powers and of judicial independence that lays at the foundation of the Italian model of JSG, with a

\footnotetext{
${ }^{1}$ European Commission for Democracy Through Law (Venice Commission), Opinion n. 403/2006 of 22 June 2007, Judicial Appointments, Report adopted by the Venice Commission at its 70th Plenary Session (March 16-17, 2007), <www.venice.coe.int>.

${ }^{2}$ See DAVId Kosař, Perils of Judicial Self-Government 126 et seq. (2016), in particular at 135.

${ }^{3}$ Article 83 of the Constitution of the IV French Republic (27 October 1946) established a "High Council of the Judiciary". However, judges were not the majority.
} 
particular emphasis on the balance between the so-called external and internal independence (B.I). It also provides an overview of the main actors involved in the judicial government and of their interactions (B.II). Section $C$ analyses the impact of this model of JSG on the values of independence (C.I) and judicial accountability (C.II) by showing how and to what extent these have been achieved following the establishment of the CSM in 1958 until nowadays. The conclusion takes stock of the Italian model of JSG, stressing the achieved results - and the reasons thereof - as well as the challenges that remain open.

\section{B. Rationale and Actors of Judicial Self-Government in Italy}

\section{Judicial Self-Government and Separation of Powers in the 1948 Constitution}

The first appearance of the cornerstone institution of the Italian system of JSG, i.e. the CSM, dates back to law no. 511 of 14 July 1907, which established it as a body consisting of judges and public prosecutors partly elected by the judiciary itself, with relevant advisory powers concerning the hiring and the careers of the magistrates. ${ }^{4}$ During the fascist regime, the CSM was both deprived of its self-representative nature, and curtailed in its powers, while the administration of magistrates' careers was concentrated in the hands of the Ministry of Justice ('MJ'), to the obvious detriment of the independence of the judiciary. ${ }^{5}$ After the fall of the authoritarian regime, the CSM was soon given back its elective character and some relevant powers through law no. 511 of 31 May 1946, just before the Constituent Assembly started its work. ${ }^{6}$ However, while a certain continuity between the pre-Republican and the current CSM can be traced, the 1948 Constitution strengthened its autonomy and competences in such a way that the current CSM can rightly be considered as an innovation of the Republican Constitution. ${ }^{7}$

The institution of the CSM as the cornerstone of the independence of the judiciary was never put into question during the work of the Constituent Assembly. Indeed, already

\footnotetext{
${ }^{4}$ Law of 14 July 1907, n. 511, Riforma dell'ordinamento giudiziario, promoted, together with Law of 27 July 1908, n. 438, Per le guarentigie e la disciplina della magistratura, by the then Minister of Justice Vittorio Emanuele Orlando. See also Royal Decree of 14 December 1921, n. 1978, Sull'ordinamento giudiziario, so-called Decree 'Rodinò'. See Antonella Meniconi, Storia della magistratura italiana (2013).

${ }^{5}$ See Royal Decree of 30 December 1923, n. 2768, Testo unico delle disposizioni sull'ordinamento degli uffici giudiziari e del personale della magistratura, so-called Decree 'Oviglio', and Royal Decree of 30 January 1941, n. 12, Ordinamento giudiziario, so-called 'ordinamento Grandi'. See Guido Neppi Modona, La magistratura ed il fascismo, POLITICA DEL DIRITTO 596 (1972).

${ }^{6}$ Royal Legislative Decree of 31 May 1946, n. 511, Guarentigie della magistratura, so-called Decree 'Togliatti'. Notice that the Decree purposely bears the same name as the 1908 Law (supra note 4), to express the reestablishment of the liberal guarantees after the Fascist authoritarianism.

${ }^{7}$ ALESSANDRO PIZZORUSSO, L'ORGANIZZAZIONE DELLA GIUSTIZIA IN ITALIA: LA MAGISTRATURA NEL SISTEMA POLITICO E ISTITUZIONALE 40 (1990).
} 
within the Study Commission established by the Ministry for the Constituent Assembly and then throughout all phases of the Constituent Assembly's work, a broad agreement was reached on the following point: in order to secure the independence of the judiciary it is necessary that the Constitution releases magistrate careers from the will of the executive power. ${ }^{8}$ Therefore, the administrative functions concerning the status of the magistrates, as well as disciplinary proceedings against them, had to be removed from the sphere of competence of the MJ and assigned to an independent body.

Unlike in other legal orders, the lack of an at least indirect link between the judiciary and the source of the sovereignty - the people - has never been considered problematic under the perspective of the democratic principle and of the principle of popular sovereignty embodied in the first Article of the Italian Constitution. ${ }^{9}$ This is because the judiciary is not understood as a law-creating but as a law-applying authority. Therefore, the source of its legitimacy is not to be found in its appointment by the representatives of the people, but in its subordination to the legislature's will only, as Article 101, para. 2 spells out. ${ }^{10}$ After all, judges and public prosecutors are civil servants recruited by public selection, ${ }^{11}$ whose independence is so crucial to the rule of law that must be protected by special arrangements. This justifies their freeing from the executive power to which all civil servants in principle are subordinated. ${ }^{12}$

Interestingly enough, the principle that power over magistrates' careers was to be taken away from the executive power and bestowed to an independent body was meant to protect their independence, not only from other powers - and notably from the executive power - but also from potential pressures and influences coming from within the judiciary. In the deliberations of the Constituent Assembly, indeed, the concept of judicial independence clearly refers both to the so-called 'external independence' - i.e., from outside the judiciary - and to the so-called 'internal independence' - i.e., from the

\footnotetext{
${ }^{8}$ See Ministero per la Costituente, Commissione per studi attinenti alla riorganizzazione dello Stato (so-called 'Commissione Forti'), Relazione all'Assemblea Costituente, 1 Relazione della prima Sottocommissione 'Problemi COSTITUZIONALI' 32 and 256-257 (1946), available at http://legislatureprecedenti.camera.it/.

${ }^{9}$ Article 1: "Italy is a Democratic Republic, founded on work.//Sovereignty belongs to the people and is exercised by the people in the forms and within the limits of the Constitution."

${ }^{10}$ Article 101, para. 2 of the Italian Constitution: "Judges are subject only to the law".

${ }^{11}$ So Article 106, para. 1 of the Constitution. Paras. 2 and 3 of the same Article provide for some limited exceptions.

${ }^{12}$ This understanding of the role of the judge does not necessarily lead to a mechanical conception of the judicial function: in Italian legal scholarship - as everywhere - the "creative" nature of the interpretation of law has long been acknowledged.
} 
influence of senior/more powerful magistrates over younger ones. ${ }^{13}$ Article 107, para. 3 , in particular, testifies to this concern by providing that "magistrates are distinguished only by their different functions", which shall exclude any form of hierarchy within the judiciary. This essential aspect is frequently overlooked by the documents of supranational institutions supporting the Italian model, which focus primarily on the potential threats to judicial independence coming from the executive power. ${ }^{14}$

While the institution of the CSM as an independent body was not disputed as such, its composition triggered an interesting debate within the Constituent Assembly. The project originally elaborated by the Commission for the Constitution provided for a mixed composition. ${ }^{15}$ According to this project, the CSM comprised a number of members elected half by the judiciary and half by the Parliament as well as the President of the Republic serving as its President and two Vice-Presidents. The members elected by the judiciary are called 'gowned members' (membri togati), for they belong to the judiciary; the latter are called 'lay members' (membri laici), for they do not belong to the judiciary. However, during the discussion in the plenary of the Constituent Assembly, two opposite views measured against each other. ${ }^{16}$

On the one hand, some constituents opposed the project claiming that proper independence of the judiciary could be achieved only by full self-government of the judiciary. In their view, the presence in the CSM of lay members elected by the Parliament amounted to an interference by the legislative and executive powers on the judiciary. On the other hand, others upheld the project by stressing the need not to detach the judiciary from the society and not to release it from the system of checks and balances, and from the supervision of the Parliament in particular. In their view, a CSM consisting of magistrates only would have turned the judiciary into a 'closed caste'. These two positions reflected two different understandings of the principle of separation of powers. Those supporting the exclusion of lay members from the CSM adhered to a rigid conception of the separation of powers, aiming at avoiding any potential influence of the legislative and

\footnotetext{
${ }^{13}$ See, in particular, the remarks of the Member of the Constituent Assembly Aldo Bozzi in the afternoon session of Nov. 6, 1947, in AtTI Della AsSemblea Costituente 1803 (1947), available at http://legislatureprecedenti. camera.it/.

${ }^{14}$ Kosař, supra note 2, at 130.

${ }^{15}$ See Article 97, para. 2, of the draft Constitution elaborated by a Commission consisting of 75 Members of the Constituent Assembly and presented to the Presidency of the Constituent Assembly on 31 January 1948, available at http://legislatureprecedenti.camera.it/.

${ }^{16}$ These two opposing views are well summarized in the remarks of the Member of the Constituent Assembly Giuseppe Bettiol in the afternoon session of Nov. 7, 1947, in Atti della Assemblea Costituente, supra note 13, at 1849-1850. As to the reason bringing to refusing full self-government, see Simone Benvenuti, Magistrature, in COSTITUENTI OMBRA. ALTRI LUOGHI E ALTRE FIGURE DELLA CULTURA POLITICA ITALIANA NELLA STAGIONE DELLA COSTITUENTE 394 et seq. (Andrea Buratti \& Maurizio Fioravanti eds., 2010).
} 
the executive powers over the judiciary. By contrast, the supporters of a mixed composition stuck to a less strict reading of the separation of powers, which considers that all powers, including the judiciary, although separated, must be coordinated and be subject to the supervision of the democratic institutions.

A compromise was finally reached by decreasing the number of the lay members so that the gowned members were granted the majority within the Council. But the decrease of power of the lay members was balanced by requiring the CSM to choose its vice-president from among the lay members. While the influence of the lay members within the CSM was significantly curtailed with respect to the initial proposal, the idea of a strict selfgovernment of the judiciary was rejected, and so the underlying idea of a rigid separation of the powers. While protected from undue influence by the executive and other powers, the judiciary is neither secluded from interaction and cooperation with other powers, nor is it unaccountable or detached from democratic controls. It is rather embedded in a system of checks and balances, from which no power can be exempted.

Firstly, JSG through the CSM is essentially administrative self-government. The CSM does not have the power to rule on the organization of the judiciary. It is a law-applying body, not a law-making one. The Constitution does not leave any room for doubt on this point. Article 105 requires the CSM to exercise its competences "in accordance with the rules on the organization of the judiciary", while Article 108, para. 1, reserves those rules for the Parliament. It is then the Parliament that has to lay down the rules on the judiciary, which are then applied by the CSM. This is essential to accommodate the autonomy of the judiciary with the democratic principle. Furthermore, as for all administrative bodies, the measures taken by the CSM do not escape judicial control. All CSM measures concerning the status of judges and prosecutors can be challenged before the administrative court in Rome, whose decisions are appealed before the Council of State. ${ }^{17}$ This is quite a contentious issue, for the review performed by the administrative court is sometimes considered to be too intrusive. ${ }^{18}$ Excesses aside, however, judicial review of its measures remains essential for embedding the CSM in a fabric of checks and balances, and in particular to protect the 'internal' judicial independence.

Secondly, as mentioned above, the CSM itself is not representative of the judiciary alone, but it also consists of members elected by the Parliament, from whom the vice-president is then chosen. Furthermore, the presidency of the CSM is given to the President of the Republic. ${ }^{19}$ In practice, the President of the Republic very rarely presides over the CSM. But

\footnotetext{
17 Article 17 of Law 195 of 1958 (infra 23), as amended by Art. 4, Law 12 April 1990, n. 74. The measures concerning disciplinary responsibility are by contrast to be challenged before the Supreme Court.

${ }^{18}$ See luca GeninatTI SATÉ, IL RUOlo costituZIONALE DEL C.S.M. E I LIMITI AL SINDACATO GIURISDIZIONALE DEI SUOI ATTI (2012).

19 ARIanNa Moretti, Il Presidente della Repubblica come PRESIDENTE DEL CSM (2011).
} 
his presidency is nevertheless extremely relevant to securing the balance among the powers. Being a super partes authority, detached and independent from the ruling political majority, the President of the Republic certainly contributes to securing the independence of the judiciary. But in his capacity of guarantor of the balance of powers, as designed by the Constitution, he can also help foster loyal cooperation among the institutions and redress potential abuses of power by the CSM itself. ${ }^{20}$

Thirdly, cooperation and mutual review are ensured between the CSM and the MJ. While the very institution of the CSM is meant to take away from the MJ those administrative powers that could affect judicial independence, the MJ still retains the political responsibility for the proper functioning of the administration of justice, ${ }^{21}$ as will be stressed in Section C.I.1.

\section{The Institutional Actors of Judicial (Self-)Government}

If one moves from the constitutional to the sub-constitutional level, one will see that the CSM, whose legislative regulation has changed over time, is also embedded in a complex framework of judicial (self-)government. This comprises, besides the MJ, a set of other bodies established by ordinary laws.

According to constitutional provisions, the CSM is composed of three members by right: the President of the Republic, the First President and the General Prosecutor of the Supreme Court. Two-thirds of the remaining members are elected by all the magistrates and are magistrates themselves, the so-called gowned members. An important clarification is now needed. As the reader might have noticed, in this paper we always speak of "magistrates" and not of "judges". In Italy, public prosecutors indeed enjoy in principle the same degree of independence as judges and the careers of the two are not separated. A single recruitment procedure applies to both categories: a magistrate who has passed through the selection process chooses whether he or she prefers to work as a judge or as a public prosecutor. The CSM is meant to protect the independence both of judges and of public prosecutors and is responsible for the administration of the careers of both. The gowned members of the CSM are then either judges or public prosecutors ("magistrates"). ${ }^{22}$ The remaining third of the elective members are elected by the

\footnotetext{
${ }^{20}$ Cf. Nicolò ZANON \& FRANCESCA BIONDI, IL SISTEMA COSTITUZIONALE DELLA MAGISTRATURA 19 (2008).

${ }^{21}$ See Article 110 of the Italian Constitution: "Without prejudice to the authority of the High Council of the Judiciary, the Minister of Justice has responsibility for the organization and functioning of those services involved with justice." Some scholars term this a system of 'dual governance', Francesco Contini \& Antonio Cordella, ICT $e$ giustizia: successi e fallimenti tra legami deboli e governance duale, in SOGGETTI SMARRITI. PERCHÉ INNOVAZIONE E GIUSTIZIA NON SI INCONTRANO (QUASI) MAI 52, 58 (Davide Carnevali ed., 2010).

${ }^{22}$ Law of 28 March 2002, n. 44, Modifiche alla legge 24 marzo 1958, n. 195, recante norme sulla costituzione e sul funzionamento del Consiglio superiore della Magistratura, established the election of ten judges by judges themselves, of four prosecutors by prosecutors, and of two magistrates of the Supreme Court.
} 
Parliament in joint session from among full university law professors and lawyers with at least fifteen years of practice. The Council's term lasts four years and its members cannot be immediately re-elected. According to Article 105, the CSM 'has jurisdiction for employment, assignments and transfers, promotions and disciplinary measures concerning judges, in accordance with the norms governing the judiciary'.

Since the entry into force of the Constitution on 1 January 1948, the constitutional provisions on the CSM have not been amended. However, the Constitution confines itself to determining the proportion between the gowned and the lay members $(2 / 1)$, but it does not regulate either the total number of Council members or how they must be elected. The legislature is accorded wide discretion in shaping the composition of the Council. As for the total number of members, this was initially set at twenty-four by Law no. 195 of 1958 (hereinafter: 'Law on the CSM'), which established the CSM, implementing the constitutional provisions no less than ten years after the entry into force of the Constitution. ${ }^{23}$ The number was then increased to thirty-three in 1975 and finally reduced to twenty-seven members in 2002. The election of lay members was never disputed. The Law on the CSM provides that these are elected by the Parliament in joint session with a majority of $3 / 5$ of the MPs, whereas after the second scrutiny a majority of $3 / 5$ of the voting MPs is sufficient. This prevents the ruling majority from appointing 'its own candidates' because an agreement with the opposition is normally required, for the ruling majority alone generally cannot reach the $3 / 5$ threshold. While this rule has never been amended, the electoral system for the gowned members has always been under dispute and was subject to no less than six amendments, which are analyzed in Section C.I.3.

From an organizational point of view, it would be a mistake to consider the CSM a homogenous body over time. When established in 1958, its secretariat counted six magistrates working full-time and a staff of seven employees. Nowadays, the CSM, which commands a budget of roughly 35 million Euros a year, counts approximately 230 employees. The secretariat comprises twelve magistrates, while six magistrates work at the internal service for study and documentation ('Ufficio studi e documentazione') established in $1990 .^{24}$ This gives an idea of the increasing complexity and institutional capacity of the CSM.

Other than the CSM, the Constitution only mentions one other actor responsible for judicial government, namely the MJ. In theory, the division of labor between the CSM and the MJ is sufficiently clear-cut. While Article 104 of the Constitution reserves to the CSM all

\footnotetext{
${ }^{23}$ Law of 24 March 1958, n. 195, Norme sulla costituzione e sul funzionamento del Consiglio superiore della Magistratura.

${ }^{24}$ Successive laws increased the size of the secretariat from six to eight in 1967, to twelve in 1977. As mentioned, the employees' staff witnessed an even sharper growth: twenty-four in 1967, ninety-six in 1977, up to slightly more than two-hundred in 1990.
} 
measures concerning the status of the judges and their disciplinary responsibility, Article 110 charges the MJ with 'the organization and functioning of justice services'. This means that what potentially affects the independence of the judges - essentially the administration of their careers - belongs to the CSM, while it remains within the jurisdiction of the MJ to provide the services necessary to support the proper administrative functioning of the judiciary. In practice, however, this division of labor has proven far less clear-cut, as section C.I.1 will show.

Article 107, para. 2, of the Constitution enables the MJ to instigate a disciplinary proceeding against a magistrate, provided that the decision is reserved for the CSM, notably for its disciplinary section, consisting of the CSM vice-president and five members, four of whom are gowned members. ${ }^{25}$ The MJ does not enjoy a monopoly on the instigation of a disciplinary proceeding, for the law has extended the same power to the General Prosecutor of the Supreme Court. The rationale of this power of the MJ is twofold. On the one hand, it relates to Article 110: being responsible for the proper functioning of the services related to justice, the MJ could instigate a disciplinary proceeding to redress those magistrates' behaviors that jeopardize the proper administrative functioning of these services. ${ }^{26}$ On the other hand, the MJ's power to instigate a disciplinary proceeding proves the Constituent Assembly's purpose not to turn the judiciary into a closed corporation. The magistrates' behavior is not under the surveillance of the magistrates only, but it is also subject to the scrutiny of an actor that is external to the judiciary ${ }^{27}$ and bears political responsibility before the Parliament.

The law confers to the MJ the authority to exercise 'high surveillance' on all judicial offices and on all judges. This consists of regular 'inspections' and specific 'administrative inquiries'. This inspection power, however, cannot affect either the independence of the judges in the exercise of their functions or the content of judicial decisions. Furthermore, it is worthy to note that supervision is carried out by the General Inspectorate of the Ministry of Justice, which is composed only of magistrates. Traditionally, magistrates also hold other key positions in the Ministry, such as heads of directorates and cabinets.

Except for the CSM and the MJ, the Constitution does not mention any other actor of judicial administration. After all, since all decisions concerning the status of the judges and their disciplinary responsibility have been centralized in the CSM, there is little room for other actors in the (self-)government of the judiciary. They can only play a consultative and

\footnotetext{
${ }^{25}$ Notice that the disciplinary section enjoys wide autonomy within the CSM, for its decisions are final and not subject to review by the plenum. In its judgment of 2 February 1971, n. 12, the Constitutional Court upheld this by stating that the Constitution does not require that all competences of the CSM are to be exercised by the plenum: the legislature enjoys wide discretion in defining the CSM's organization.

${ }^{26}$ See Constitutional Court, judgment of 2 December 1963, n. 168.

${ }^{27}$ FRANCESCA BIONDI, LA RESPONSABILITÀ DEL MAGISTRATO. SAGgIO DI DIRITTO COSTITUZIONALE 246 (2006).
} 
ancillary role to the CSM. This certainly helps to protect the 'internal' independence of the magistrates, releasing them from the influence, for example, of court presidents. However, it also burdens the CSM with a huge number of administrative tasks, and proposals have been made to decentralize the functions of the CSM.

As for court presidents, until 2006 they were appointed without a fixed term. In 2006, a four-year term, renewable one time, was introduced to avoid the consolidation of personal powers. ${ }^{28}$ Their most significant role consists in assigning, in cooperation with the judicial boards, the court's magistrates to the civil or criminal branch and to the respective sections, and in assigning the cases to the court's sections and to the specific judges or colleges. The exercise of these powers, under the hierarchical control of the MJ before the establishment of the CSM, now envisages the participation of multiple actors. The President of the Court of Appeal, having heard the opinion of the judicial board, proposes to the CSM a list for approval. Then the cases are assigned to the sections and to the single judges or colleges by the court's president, according to general criteria previously approved by the CSM (the so-called 'sistema tabellare'). Appeal to the CSM is granted against courts' presidents' decisions. This system is essential to secure the respect of the principle of the natural judge laid down by Article 24 of the Constitution. Court presidents also have a number of administrative tasks related to the organization and the management of the offices and participate in the process of evaluating judges.

In each district of an appeal court, there is a judicial board ('consiglio giudiziario') and a similar body exists for the Supreme Court ('Consiglio direttivo della Corte di Cassazione'). Judicial boards were first established in 1904, ${ }^{29}$ became elective in 1946 and underwent significant reforms in 1966-67 and then again in 2006-2007 when their place was strengthened and their composition extended to advocates and law professors. They now consist of both elected magistrates of the relevant district and lay members, in a proportion of two to one, and are presided over by the President of the Court of Appeal. Their main powers consist in issuing reasoned opinions on the professional evaluations of magistrates and their promotion, for which the lay members can only submit their views, thus working as a source of information. Besides that, judicial boards also give their advice in the procedure for assigning judges and cases and supervise the functioning of the district's offices by referring to the MJ, if need be, any dysfunctionality they may detect. ${ }^{30}$

\footnotetext{
${ }^{28}$ On the appointment procedure, see infra C.I.1.

${ }^{29}$ Royal Decree of 7 January 1904, n. 2, which transferred to the newly established boards the advisory powers previously belonging to court presidents on appointment, promotions and transfers.

${ }^{30}$ The law gave them also the power to make proposals to the School of the newly established School of the Judiciary, thus including them in the definition of traning policies.
} 
Finally, in 2006, the competences concerning education and training were transferred from the CSM to the newly established, autonomous, High School of the Judiciary. The board of the High School consists of twelve members (seven magistrates, three professors, and two lawyers) partly appointed by the CSM (seven members) and partly by the MJ (five members). The establishment of a judicial school autonomous from the CSM responds firstly to the need to provide training open to the society, not confined behind the judicial walls. ${ }^{31}$ But it also follows a European trend towards a better and more efficient training of judges.

\section{The Impact of the Italian Model of Judicial Self-Government on the Independence and Accountability of the Judiciary}

\section{Consolidating External Independence at the Expense of Internal Independence?}

\section{Independence from the Executive}

The constitutionalization of the CSM aimed first at insulating the judiciary from the executive power, and namely from the MJ. Yet, the law on the CSM was passed no less than ten years after the Constitution's entry into force. Thus, initially the MJ was able to exercise his influence, although senior magistrates, judicial boards, the old CSM, and courts presidents de facto co-determined some of his decisions, constraining the executive's power somewhat. Furthermore, the disciplinary power of the MJ was limited by a disciplinary court fully composed of senior judges. ${ }^{32}$

Once established, it took some time for the CSM to gain full autonomy from the MJ in the exercise of its powers. The Law on the CSM made all of this body's decisions conditional upon a previous proposal by the MJ, who was therefore in a position to influence the operation of the CSM. It was not until 1963 that the Constitutional Court held this provision unconstitutional for violating the autonomy of the CSM. ${ }^{33}$

Interestingly enough, in this decision, the Constitutional Court rejected a narrow reading of the powers of the MJ. Accordingly, Article 110 of the Constitution does not entrust the MJ only with the task of managing the administrative staff (clerks, secretaries and other employees), buildings, furniture, and other resources essential to exercise the judicial functions. It also empowers the MJ to organize courts and tribunals efficiently and to

\footnotetext{
${ }^{31}$ Valerio Onida, Perché la scuola della magistratura deve essere autonoma, QUESTIONE GIUSTIZIA 1 (2016).

${ }^{32}$ Art. 236 of Royal Decree 12/1941 (supra note 5) and Art. 24 of Royal Legislative Decree 511/1946 (supra note 6).

33 Judgment $168 / 1963$ (supra note 26). The CSM was thus recognized as having the power to initiate the procedure independently.
} 
secure their functioning. This means that, while any influence of the executive on the status of magistrates must be ruled out, overlaps between the powers of the CSM and of the MJ in the management of the judicial machinery are unavoidable, and the two have to loyally cooperate for the sake of the proper functioning of the judicial services. The appointment of court presidents is a case in point that testifies to this need for cooperation.

Since the appointment as a court president is clearly an important step in a judge's career and can bear direct consequences on courts' decisional output, there is no doubt that the relevant power belongs to the CSM. However, since court presidents perform not just purely judicial functions but also those related to court administration and organization, the MJ must be given a say in the appointment procedure. Otherwise, the MJ, who is in charge of the proper administration and functioning of the judicial machinery, would be accountable before the Parliament for the administrative deficiencies ascribable to court presidents, whom the MJ did not contribute to choosing and cannot remove. Article 17 of the Law on the CSM strikes a balance between the need to secure judicial independence and the need to respect the constitutional prerogatives of the $\mathrm{MJ}-\mathrm{a}$ balance between Article 105 and Article 110 of the Constitution. It provides that the appointment of court presidents is decided upon by the CSM based on a proposal made by an internal commission 'in concert' with the MJ. However, what 'in concert' exactly means is anything but clear.

Frictions between the MJ and the CSM for the appointment of court presidents materialized in particular at the beginning of the 1990s, when the MJ refused to follow up the appointment of the President of the Court of Appeal of Palermo, for he had not agreed on the proposal made by the commission, which had been approved by the CSM. The conflict was decided by the Constitutional Court. In its view, the commission and the MJ must engage in a real dialogue in accordance with the principle of loyal cooperation. If an agreement cannot be reached, the CSM can then select a candidate who lacks the support of the MJ, provided that it gives reasons for departing from the MJ's view. The Court thus ruled out a veto power of the MJ, although the intervention of the MJ must be considered something more than simply consultative. ${ }^{34}$ The Constitutional Court reiterated in 2003 that the CSM must truly and fairly seek an agreement: therefore, concert relates to the procedure and the method by which the choice is made, not the final outcome of the decision. ${ }^{35}$

Taking a bird's eye view, it is widely recognized that independence from the executive - of both the judiciary and individual judges - has been progressively and substantially achieved also in its output dimension. This does not rule out in principle the possibility for

\footnotetext{
${ }^{34}$ Constitutional Court, judgment of 9 July 1992, n. 379.

${ }^{35}$ Constitutional Court, judgment of 18 December 2003, n. 380.
} 
the $\mathrm{MJ}$ to unduly influence the functioning of the judicial machinery by resorting to its Article 110 powers or through its own normative powers or those delegated to the Government by the Parliament. In that respect, the National Association of Magistrates raised on several occasions the potential negative impact of inadequate resources on the efficient and independent functioning of the judicial machinery. ${ }^{36}$

\section{Independence from the Legislative}

The same assessment holds true if one turns to the legislative branch as the second constitutional power able to encroach on judicial independence. The judiciary is not completely insulated from the legislative branch since, as mentioned in Section B, the Parliament holds the power to define the legislative framework in which judicial administration bodies operate, to decide the judiciary's budget and overall structure, and also participates in judicial government by electing $1 / 3$ of the CSM members. Even though Parliament's representatives are only one third among all appointed members, one of them holds the vice-presidency. Yet, the ability of non-judicial members to play a role very much depends on their profile and on the CSM's internal dynamics. Between 1958 and 1976, their profile was strongly political, while between 1976 and 1994 a more neutral character emerged, seemingly related to greater autonomy of the CSM. ${ }^{37}$ After 1994, the profile of lay members tended to politicize again. As to the internal dynamics, power relations depend on the ability of gowned members to coordinate and on the ability of the vice-president to exploit divisions among them or to determine the CSM agenda, as happened between 2014 and $2018 .^{38}$

In any case, members elected by the Parliament are a minority and they rarely act in concert. Therefore, the Parliament and even less so the parliamentary majority is hardly able to affect the independence of individual judges in the process of appointment, promotion, etc. By contrast, an influence in the opposite direction, from the judiciary to the Parliament, can be observed. Indeed, the judiciary has been strong enough to lobby the legislative bodies, thus influencing limited aspects of the legislative framework. For

\footnotetext{
${ }^{36}$ See for example the intervention of the Prosecutor of the Court of Appeal of Milan on the occasion of the opening of the judicial year in January 2016, <http://www.radioradicale.it/scheda/465315/milano-cerimonia-diinaugurazione-dellanno-giudiziario-2016>.

37 Daniela Piana \& Antoine Vauchez, Il Consiglio superiore della magistratura 142 et seq. (2012).

${ }^{38}$ This explains the battles over the election of the vice-president and those addressing the balance between the powers of the plenum and the powers of the vice-president (and of the President). SIMONE BENVENUTI, IL CONSIGLIO SUPERIORE DELLA MAGISTRATURA FRANCESE. UNA COMPARAZIONE CON L'ESPERIENZA ITALIANA 26 et seq. (2010).
} 
example, under the pressure of judicial initiatives, magistrates' salaries, pensions, and retirement bonuses were substantially increased in $1984 .{ }^{39}$

The CSM too was able to influence legislation. For example, in 1979 it failed to organize autonomously the written and oral exams that new magistrates had to pass two years after their entry in the judiciary. Urged by the CSM, the Parliament subsequently abolished these examinations. ${ }^{40}$

\section{Old and New Forms of Internal Independence}

In sum, the institutional framework and its de facto functioning guarantee a high degree of external independence both of the judiciary as a whole and of single judges. However, the problem of internal independence was less easily solved.

The establishment of the CSM in 1958 did not immediately challenge the undue influence senior magistrates used to exercise on junior colleagues. The Law on the CSM reserved to Supreme Court magistrates six of the fourteen elective positions. ${ }^{41}$ If one considers that the first President and the General Prosecutor of the Supreme Court are members by law, it appears that half of the gowned members of the CSM were magistrates of the Supreme Court. Besides distorting the representative nature of the CSM - for Supreme Court judges comprised, and comprise, clearly far less than half of the magistrates - this significantly put into question the internal aspect of judicial independence by giving an extremely influential role to senior magistrates over the career of their younger colleagues.

This situation changed substantially with reforms of the balance between senior and younger magistrates, which reflected a process of democratization of the judiciary. ${ }^{42}$ Law no. 695 of 22 December 1975, among others, raised the number of CSM members and slightly redressed the balance in favor of younger magistrates. ${ }^{43}$ Law no. 1 of 3 January 1981 considerably reduced the number of seats reserved for high magistrates ${ }^{44}$ and Law

\footnotetext{
${ }^{39}$ Giuseppe Di Federico, Costi e implicazioni istituzionali dei recenti provvedimenti giurisdizionali e legislativi in materia di retribuzioni e pensioni dei magistrati, 35 RIVISTA TRIMESTRALE DI DIRITTO PUBBLICO 331 (1985); FRANCESCA ZANNOTTI, LA MAGISTRATURA, UN GRUPPO DI PRESSIONE ISTITUZIONALE. L'AUTODETERMINAZIONE DELLE RETRIBUZIONI 154 (1989).

${ }^{40}$ Di Federico, supra note 39. This decision was justified by the concern for greater individual independence of young magistrates.

${ }^{41}$ Article 23 of the Law on the CSM. In its judgment 168/1963 (supra note 26), the Constitutional Court refused to hold this provision unconstitutional; in its view, the overrepresentation of Supreme Court magistrates was a legitimate choice of the legislature, in view of the longer experience of these high magistrates.

${ }^{42}$ For an overall analysis, GIAMPIETRO FERRI, MAGISTRATURA E POTERE POLITICO. LA VICENDA COSTITUZIONALE DEI MUTAMENTI DEL SISTEMA ELETTORALE E DELLA COMPOSIZIONE DEL CONSIGLIO SUPERIORE DELLA MAGISTRATURA (2005).

${ }^{43}$ Article 3 of Law 695/1975.

${ }^{44}$ Article 15 of Law 1/1981.
} 
no. 74 of 12 April 1990 finally limited the positions of elected Supreme Court magistrates to only two, ${ }^{45}$ so that the problem of the predominance of senior magistrates within the CSM can now be considered definitively overcome. Table 1 visualizes the progressive decrease of the predominant role of Supreme Court magistrates within the CSM.

Table 1: Ratio of Supreme Courts Magistrates within the CSM (1958-2002)

\begin{tabular}{|l|l|l|l|l|}
\hline & $\begin{array}{l}\text { CSM Members, } \\
\text { including de jure } \\
\text { members }\end{array}$ & $\begin{array}{l}\text { Supreme Court } \\
\text { Magistrates out of of Supreme } \\
\text { CSM Gowned } \\
\text { Members* }\end{array}$ & $\begin{array}{l}\text { \% of Supreme } \\
\text { Court Magistrates } \\
\text { out of Gowned } \\
\text { Members* }\end{array}$ & $\begin{array}{l}\text { Court Magistrates } \\
\text { within the CSM } * *\end{array}$ \\
\hline 1958 & 24 & $8 / 16$ & $50 \%$ & $35 \%$ \\
\hline 1975 & 33 & $10 / 22$ & $45 \%$ & $31 \%$ \\
\hline 1981 & 33 & $6 / 22$ & $27 \%$ & $19 \%$ \\
\hline 1990 & 33 & $4 / 22$ & $18 \%$ & $13 \%$ \\
\hline 2002 & 27 & $4 / 18$ & $22 \%$ & $15 \%$ \\
\hline
\end{tabular}

* Gowned members include also 2 de jure members.

** Reported features do not take into account the Head of State, who rarely presides over the CSM and does not cast a vote.

(Sources: Law 195 of 24 March 1958; Law no. 695 of 22 December 1975; Law no. 1 of 3 January 1981; Law no. 74 of 12 April 1990; Law no. 44 of 28 March 2002)

While legislative reforms have proven successful in contrasting the undue influence of senior magistrates over younger ones, no legislative reform aptly addressed what is now considered the main threat to judicial internal independence, i.e. the power of the 'correnti'. These are organizations acting within the association that groups together all Italian magistrates, the National Association of Magistrates ('Associazione Nazionale Magistrati - ANM'). The ANM, which was established in 1944 as a successor to the General Association of Magistrates, ${ }^{46}$ acts as a forum in which judges discuss judicial policies. ${ }^{47}$ Initially, senior magistrates ruled the ANM. However, in 1957 a new generation of magistrates gained the leadership and alienated the senior magistrates from the ANM. Starting from the 1960s, the process of institutionalizing these groups of magistrates

\footnotetext{
${ }^{45}$ Article 5 of Law 74/1990.

${ }^{46}$ The Associazione Generale dei Magistrati d'Italia (AGMI) was founded in 1909 and had over 2,000 associate members in 1914, for a judicial body comprising between 4,000 and 5,000 magistrates. It was banned in banned in 1926, Royal Decree of 16 December 1926. See Pizzorusso, supra note 7, at 55-60; Antonella Meniconi, La storia dell'associazionismo giudiziario: alcune notazioni, 4 QUESTIONE GIUSTIZIA 220, 223-4 (2015).

${ }^{47}$ Carlo Guarnieri, Judicial Independence in Europe: Threat or Resource for Democracy, 3 REPRESENTATION 347, 350 (2013). On the relevance of 'correnti' for understanding the development of the Italian judicial organisation, see ALESSANDRO GIULIANI \& NICOLA PICARDI, LA RESPONSABILITÀ DEL GIUDICE 154 et seq. (1995).
} 
brought about the formal establishment of the 'correnti', whose role within the CSM was magnified by, among other things, legislative reforms of the electoral system.

When the CSM was established in 1958, magistrates could vote only for candidates belonging to their own category. ${ }^{48}$ Magistrates from the Supreme Court elected six representatives in one single nation-wide constituency, while magistrates from the Court of Appeal and from the Tribunal elected four representatives each, in four different constituencies (one per constituency). ${ }^{49}$ Law 1198/1967 abandoned the category-based system of representation established by the Law on the CSM. Magistrates thus voted for candidates from all three categories within one national constituency. ${ }^{50}$ The candidates of the Supreme Court had therefore to seek the support of lower ranking magistrates in order to be elected. ${ }^{51}$

Law no. 695 of 22 December 1975 replaced the majority principle with a system of proportional representation. Elections were held within a single nation-wide constituency based on lists that included candidates from any category in the amount of those to be elected. ${ }^{52}$ De facto, this required the presentation of lists of candidates with the support of nationally structured organizations such as 'correnti', which were only able to support the CSM's candidates at the national level. Lists therefore came to be determined by the secretariats of the 'correnti'.

The 1967 and 1975 electoral system reforms emancipated lower magistrates from top magistrates and provided the CSM with a substantively pluralist structure that was reflected in their decision-making dynamics. Pluralism was supposed to originate from the proportional representation of the socially and ideologically fragmented judiciary. The potential diversification of CSM judicial members was thought to allow for mutual checks and balances among the representatives of the ANM's 'correnti' in the CSM and thus to improve the CSM's decision-making autonomy.

Over the years, however, 'correnti' became an actor potentially undermining independence in two ways. Although not explicitly linked to a specific political party,

\footnotetext{
${ }^{48}$ Article 23 of the Law on the CSM.

${ }^{49}$ Articles 26 and 27 of the Law on the CSM

${ }^{50}$ Articles 7 and 9 of the Law on the CSM.

${ }^{51}$ However, Article 8 of the law somehow tempered the departure from the category-based logic since candidates themselves for each category were first chosen (twice the number of members to be elected) through elections according to the old system for electing members of the CSM. Magistrates from the Supreme Court elected twelve candidates in one single constituency, while magistrates from the Court of Appeal and from the Tribunal elected eight representatives each in four different constituencies (two per constituency).

${ }^{52}$ Article 5 of Law 695/1975. Lists needed to be signed by at least 150 voters.
} 
'correnti' distinguish themselves for their 'political' or 'ideological' orientation, so that it is common to speak of moderate, progressive, conservative 'correnti'. These factions each drafted candidate lists with the intent of taking their candidates to the CSM. Thus it was a candidate's affiliation and loyalty to a 'corrente', rather than merit, which was responsible for his or her election. Second, the practice of CSM decision-making, especially in the area of appointments, developed in such a way as to achieve informal agreements among 'correnti' to share vacant positions within the judiciary amongst themselves. ${ }^{53}$ This affected the legitimacy of the measures taken by the CSM, which are often criticized as biased, for they do not aim at rewarding the best magistrates for given positions, but rather those showing certain loyalties. These supposedly negative effects became apparent and the object of criticism in the political arena during the 1980s, which led to new reforms.

While keeping the proportional system of representation, Law no. 74 of 12 April 1990 replaced the nation-wide electoral district with four territorial districts and lowered the number of magistrates required to support the presentation of a list of candidates. ${ }^{54}$ The purpose was to favor territorial rather than politico-ideological representation in order to de-structure the 'correnti' and to reduce the council's politicization. However, the law introduced a $9 \%$ electoral threshold computed at the national level for the allocation of seats to lists in territorial districts. This had the effect of stabilizing the existing equilibrium among the major, already existing 'correnti', thereby limiting internal pluralism. ${ }^{55}$

Lastly, Law no. 44 of 2002 abolished the system of proportional representation without escaping the criticism of inconsistency. ${ }^{56}$ On the one hand, it requires the candidate to run for election as a single candidate and does not allow candidates to group in a list, as required by the previous regulation. ${ }^{57}$ At least in theory, this should support candidacies of autonomous magistrates, i.e. those not connected to a particular 'corrente'. On the other

\footnotetext{
${ }^{53}$ Giuseppe Di Federico, «Lottizazioni correntizie» e "politicizzazione» del C.S.M.: quali rimedi?, 10 QUADERNI COSTITUZIONALI 279, 284 \& 289 et seq. (1990); Carlo Guarnieri, Origini, problemi e sviluppo delle "correnti giudiziarie»', in I MAGISTRATI E LE CORRENTI. ALLA RICERCA DELL'INDIPENDENZA DA SE STESSI 17, 18-20 (Antonio Beveri ed., 2008).

${ }^{54}$ The four territorial districts were determined by unifying courts of appeal through drawing lots. Only the two Supreme Court magistrates were elected within a national district. The number of signatures required to support a list of candidates was 50 for the election of the two Supreme Court magistrates within the national district and 30 for the election of other representatives within the four territorial districts. See Articles 6 and 7 of Law $74 / 1990$.

${ }^{55}$ Pizzorusso, supra note 7, at 43.

${ }^{56}$ This law also provides that, besides the two magistrates of the Court of Cassazione four seats are reserved for prosecutors and ten seats for judges, Article 5 of Law 44/2002.

${ }^{57}$ Article 7 of Law 44/2002. Single candidacies need the support of a minimum of 25 magistrates and a maximum of 50 magistrates.
} 
hand, the law provides that all candidates run in a single national constituency, and not in four smaller constituencies as in the previous law. ${ }^{58}$ But it is very difficult for an autonomous candidate to find sufficient support nationwide without the support of nationwide organizations such as the 'correnti' ${ }^{59}$ Yet, for some, the 2002 reform might attenuate the grip the secretariats of the 'correnti' had on the candidacies, thereby allowing the election of 'independent' candidates. ${ }^{60}$

Following this description, two main conclusions hold. First, issues of internal institutional independence are not alien to the Italian judicial system, especially as regards the powers related to the magistrates' status. Whether this has relevant consequences on output independence is an open issue that has not been empirically investigated, even though Italian magistrates seem to perform adequately in terms of independence. ${ }^{61}$

Second, the Italian legal scholarship agrees on considering the principle of pluralism reflected in the CSM's structure and decisional dynamics - as a guarantee of (institutional) independence. ${ }^{62}$ Pluralism primarily concerns the structure of the CSM at large. First, it is finely balanced by assigning the presidency to the Head of State and appointing a lay member as vice-president of a body composed of a majority of magistrates. It also concerns the gowned and the lay components per se. It therefore results from the constitutional and legal provisions first, but also from the social conditions of the judiciary and the political contexts. The CSM's pluralist structure is essential to its proper functioning since, from a normative perspective, this prevents any principal to take control of the decision-making process. ${ }^{63}$ Put differently, the principle of independence is not exclusively related to JSG per se, which rather matters for the structural insulation of the

\footnotetext{
${ }^{58}$ Article 5 of Law 44/2002.

${ }^{59}$ Among the objectives of the law was the alignment of the election of the judicial members of the council to the system for the election of members of Parliament, and thus to achieve systematic coherence with provisions regulating the formation of the legislative branch. However, it is difficult to see why the CSM's judicial members' electoral system needed fine-tuning to make it correspond with the electoral system of Parliament, as the two bodies had different goals. In connection to this, the law aimed at facilitating the formation of stable majorities within the CSM, but, again, this objective was open to criticism, as there is no real need for stable majorities in the CSM as there is in parliamentary bodies.

${ }^{60}$ Recorded interview by Simone Benvenuti with a member of the CSM, 17 May 2018.

${ }^{61}$ tential trickledown effects on output independence.

62 Paolo Ridola, La formazione dell'ordine del giorno fra poteri presidenziali e poteri dell'Assemblea, in MAgISTRATURA, CSM E PRINCIPI COSTITUZIONALI 66 (Beniamino Caravita ed., 1994).

${ }^{63}$ Kosař, supra note 2 , at 410 .
} 
judiciary. For the individual independence to be satisfied (theoretically, also in its output dimension), the pluralist structure of the JSG body is essential. ${ }^{64}$

\section{Moderately Accountable Judges within the Least Accountable Branch?}

In European constitutionalism, judicial independence traditionally eclipsed judicial accountability. Yet, the importance of judicial accountability is now extensively acknowledged in academic scholarship. ${ }^{65}$ The Consultative Council of European Judges (CCJE), long at the forefront of promoting judicial independence, also issued an opinion on the legitimacy and accountability of the judiciary. ${ }^{66}$ In Italy, no constitutional provision explicitly refers to the accountability of judges, as opposed to other civil servants. ${ }^{67}$ Yet, mechanisms relating to career, such as appointments and promotions, and to the disciplinary process mentioned in Articles 105 and 107 of the Constitution imply an accountability relation that is defined concretely by the bodies in charge of such areas of judicial government. ${ }^{68}$ Debates within the Constituent Assembly also show that the creation of the judicial council was related to accountability issues. ${ }^{69}$ To be sure, the problem of judicial accountability has never been alien to Italian legal scholars. ${ }^{70}$

At the outset, following the description in sub-Section C.I, one cannot but stress three shifting dimensions of accountability between the 1950s and the 1980s: first, the

\footnotetext{
${ }^{64}$ The important individual guarantees for judges established by the Constitution to that effect also witness that the problem of independence was understood in much broader terms than JSG. For example, the Constitution set out the principle that "Judges are subject only to the law" (Article 101), the principle of the legal judge ("giudice naturale", Article 25.1), the rule of irrevocability (Article 107.1) and the equality of all judges (Article 107.3).

${ }^{65}$ Francesco Contini \& Richard Mohr, Reconciling independence and accountability of judicial systems, 2 UTRECHT

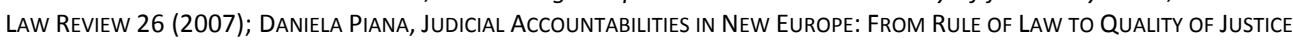
(2010); Kosař, supra note 2 , at 14.

${ }^{66}$ CCJE, Opinion No. 18 (2015), The position of the judiciary and its relation with the other powers of state in a modern democracy. The Consultative Council of European Judges (CCJE) is an advisory body of the Council of Europe on issues relating to the independence, impartiality and competence of judges. It is composed exclusively of judges.

${ }^{67}$ See Article 97 of the Italian Constitution. However, Article 28 provides that any civil servant is liable under criminal, civil and administrative law for acts in breach of individual rights.

${ }^{68}$ On the conceptualization of judicial accountability for the purpose of this article, see Simone Benvenuti, The Politics of Judicial Accountability in Italy: Shifting the Balance, 14 EUROPEAN CONSTITUTIONAL LAW REVIEW 369 (2018).

${ }^{69}$ Benvenuti, supra note 16, at 385.

${ }^{70}$ See Giuseppe Volpe, Sulla responsabilità politica dei giudici, in SCRITTI IN ONORE DI COSTANTINO MORTATI. ASPETTI E TENDENZE DEL DIRITTO COSTITUZIONALE 809 (Egidio Tosato ed., 1977); Mauro Cappelletti, Who Watches the Watchmen? A Comparative Study on Judicial Responsibility, 1 AMERICAN JOURNAL OF COMPARATIVE LAW 1 (1983); VINCENZO VIGORITI, LA RESPONSABILITÀ DEL GIUDICE (1984), and literature referred to. More recently, see Biondi, supra note 27, and LA RESPONSABILITÀ DEI MAGISTRATI (Mauro Volpi ed., 2008).
} 
weakening of external accountability and the strengthening of internal accountability; second the disempowering of the rather uniform group of top judges in favour of associated rank-and-file judges represented in the CSM; third, the prevalence of loyalty and ideology-based accountability over merit-based (professional) accountability. This had consequences on accountability as a virtue and the emergence of new professional models within the judiciary. ${ }^{71}$ The highlighted trends also explain those reforms aimed at reducing the grip of judicial associations and balancing the prevailing internal dimension of accountability.

To complete this picture, this sub-Section addresses three more specific dimensions of accountability. These relate to accountability shortcomings in the assessment and promotion of judges, to the characteristics of disciplinary responsibility, and to the recent commitment of the CSM towards greater openness in different areas of JSG. While the first two display the weaknesses of judicial accountability in the Italian system, the latter one testifies to an opposite trend towards its enhancement, especially towards external actors.

\section{The Lack of Accountability in Assessment and Promotion and the Attempts to Improve Professional Accountability}

A crucial aspect of judicial accountability in Italy is its reduced status in the area of magistrate assessment and promotion. Article 107, para. 3, of the Constitution provides that ' $[\mathrm{m}]$ agistrates are distinguished only by their different functions'. A broad interpretation of this provision has since the mid-1960s led to the abolition of judicial ranks. These were formally replaced by the functional distinction between magistrates of tribunal, appeal, and cassation. Consistently, subsequent legislative reforms abolished competitive examinations-based promotion and allowed qualification for a specific function beyond the availability of corresponding positions. ${ }^{72}$ Thus, a magistrate could become magistrate of appeal while retaining the same lower position as judge or prosecutor of a tribunal; among other things, this involved a salary increase. ${ }^{73}$ Within such a system, promotion to "higher" qualifications (functions) was based on the seniority

\footnotetext{
${ }^{71}$ Mark Bovens, Two Concepts of Accountability: Accountability as a Virtue and as a Mechanism, 33 WEST

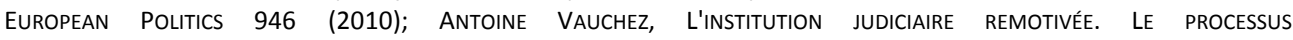
D'INSTITUtionnalisation d'UNe "NOUVelle Justice" en ITALie (1960-2000) (2004); Piana \& Vauchez, supra note 37, at 129 et seq.

${ }^{72}$ This is known as system of 'open positions' ('ruoli aperti'), Pizzorusso, supra note 7, at 45-50.

${ }^{73}$ Following the judgment of the Constitutional Court of 19 May 1982, n. 86, it was not possible to be appointed as a judge of cassation without exercising the relevant functions, but magistrates were qualified for appointment and relative salary benefits were preserved.
} 
principle, following the assessment of professional merits by court presidents and local judicial councils and a decision by the $\operatorname{CSM}^{74}$.

In its practical implementation, the new framework ended up entailing automatic promotions. The seniority rule indeed prevailed over merit-based criteria in the assessment activity, which did not take place on a regular basis. Scholars described this system succinctly as 'promotion without demerits' since the promotion was blocked only in cases of evident faults. ${ }^{75}$ From 1979 to 2007 , only $0.4 \%$ to $0.9 \%$ of magistrates received a negative assessment, usually those subject to disciplinary sanctions or to criminal charges.

This system emancipated magistrates from the judicial hierarchy, however, it generated side effects in the long run. First, inadequate assessment allowed for greater discretion of the CSM in making appointments to specific functions. ${ }^{76}$ In the course of the past 35 years, Italian magistrates have increasingly realized that their aspirations in those matters must of necessity be cultivated through personal ties with the decision makers and more particularly with their colleagues elected to the CSM as representatives of one of the 'correnti' of the National Association of Magistrates. For this very reason, almost all magistrates become members both of the ANM and of one of its 'correnti'. Membership is often a decisive factor in obtaining the desired decisions. Second, accountability in the advancement to higher qualifications (functions) was severely weakened in favoring automatism.

This blatant example of accountability perversion ${ }^{77}$ explains attempts by the legislator to increase professional accountability and to counter corporatist assessment. The Parliament approved two general reforms between 2005 and $2007 .^{78}$ While maintaining the seniority rule for advancement, the 2005 law introduced a merit-based assessment through written and oral examinations for promotion to a higher function. The 2007 law improved the system by introducing a regular evaluation process. ${ }^{79}$ During the first 28 years of a judge's

\footnotetext{
${ }^{74}$ Thirteen years' experience is required to become a judge of appeal and 28 years to become a judge of cassation. Law no. 392 of 24 May 1951, Law no. 570 of 25 July 1966 and Law no. 831 of 20 December 1973. Evaluation is a task of local judicial councils. It is based on observations by the court president and is subsequently approved by the CSM, see Article 3 of Law no. 570 of 25 July 1966.

${ }^{75}$ Giuseppe Di Federico, Statuto, carriera e indipendenza dei magistrati ordinari in Italia, 1 RIVISTA TRIMESTRALE DI DIRITTO E PROCEDURA CIVILE 1577, 1589 (1973); see also GAETANO SILVESTRI, GIUSTIZIA E GIUDICI NEL SISTEMA COSTITUZIONALE $162-169$ (1997); Guarnieri, supra note 47 , at 350 . This is a notable example of simulated judicial accountability, Kosař, supra note 2 , at 70 .

${ }^{76}$ Guarnieri, supra note 47.

${ }^{77}$ Kosař, supra note 2 , at 70 .

${ }^{78}$ Legislative Decree n. 160 of 5 April 2006, and Law no. 111 of 30 July 2007, n. 111.

${ }^{79}$ Article 2 of Law no. 111/2007, amending Article 11 of Legislative Decree n. 160/2006.
} 
career, the CSM now formulates a reasoned assessment every four years. Negative assessment can involve the obligation to attend a training course, re-appointment to a different position, and even being forbidden from exercising certain functions. Furthermore, judges cannot hold the same position for more than ten years. The law also created a commission made up of magistrates, university professors, and qualified lawyers to assist the CSM in assessing the scientific analytical competencies and skills necessary to be appointed as a Supreme Court magistrate. ${ }^{80}$

Overall, these reforms, which were approved by a center-right (2005) and a center-left (2007) majority respectively and witnessed a coincidence of intents on these aspects, did not change the JSG structure but the way JSG powers are exercised; nevertheless, they had limited impact due to inherent limits and internal resistance against implementation. From 2008 to $2016,2 \%$ of magistrates received negative assessments. ${ }^{81}$ The fact that assessing authorities (court presidents and judicial boards) are only composed of magistrates of the same district may explain this. ${ }^{82}$ The new system of assessment proved especially problematic as regards the court presidents, due to insufficient predefinition of the assessment criteria. ${ }^{83}$

\section{A Weak Disciplinary Responsibility?}

The disciplinary accountability framework involves the collaboration of the three state powers: ${ }^{84}$ the MJ initiates the procedure based on the general framework for disciplinary offenses and procedural guarantees set by the Parliament, while the disciplinary section of the CSM is in charge of the disciplinary decisions. However, in the original framework the nature of the proceeding - administrative or judicial - was ambiguous. Only in a 1971 decision did the Constitutional Court explicitly acknowledge its judicial nature. ${ }^{85}$ The Constitutional Court stated that the disciplinary section is equivalent to a court (which

\footnotetext{
${ }^{80}$ See Article 12, subsection 13, of Legislative Decree n. 160 of 5 April 2006.

${ }^{81}$ Valutazioni dal 2008 al 2016 - Dettaglio per esito http://www.csm.it/documents/21768/137951/Valutazioni/ 06706f39-ce6a-432c-bea2-45726330b9a4.

${ }^{82}$ Claudio Castelli, Commissione ministeriale per l'ordinamento giudiziario: più di un semplice maquillage, non ancora un progetto. II punto di vista di un partecipante ai lavori, QUESTIONE GIUSTIZIA (2016). The activity of judicial boards in other areas, where non-judges indeed participate, increased both in quantity and in quality. Gianluca Grasso, Note introduttive, in Gianluca Grasso (ed.), Dieci anni di riforme dell'ordinamento giudiziario, $\mathrm{V}$ FoRo ITALIANO 158 (2016).

${ }^{83}$ Grasso, supra note 82, at 223 et seq. and cited bibliography. The CSM approved new rules in 2015 (Testo Unico sulla dirigenza giudiziaria) and new rules of procedure in September 2016. Their impact is still difficult to assess.

${ }^{84}$ MICHELE VIETTI, L'ORDINAMENTO GIUDIZIARIO 60 (2003).

${ }^{85}$ Judgment of 2 February 1971, n. 12.
} 
explains the appeal to the Supreme Court, which decides upon it in joint session) ${ }^{86}$ and that 'the law, through explicit and unambiguous provisions, conferred jurisdictional character to the function carried out by the disciplinary section. ${ }^{87}$

Nevertheless, the disciplinary proceeding did not fully comply with the requirement of a fair trial. First, hearings were not public: the CSM did not introduce the possibility of public hearings until 1985, and a law formalized the principle of public hearings only in $1990{ }^{88}$ Even more important, disciplinary offenses have not been clearly defined by law until recently. Article 18 of the Royal Decree n. 511 of 1946 merely provided that a judge may be disciplined when he or she fails to maintain the duties of the office, shows untrustworthy and/or inconsiderate behavior, or damages the reputation ('prestigio') of the judiciary. ${ }^{89}$ In theory, such vagueness conflicted with Article 107, para. 1 of the Constitution, which states that a judge may be suspended or assigned to a different position following a 'decision taken based on rules set by a law'. ${ }^{90}$ In practice, even the most serious breaches of professional competencies, unless externally disclosed, were considered irrelevant, contrary to minor breaches that could harm the prestige of the judiciary. ${ }^{91}$

The disciplinary section of the CSM had to fill in these very vague concepts (duties of the office, untrustworthy behavior, reputation of the judiciary) through its own opinions. ${ }^{92}$ This had two consequences. First, the normative and the jurisdictional dimensions de facto blurred within the disciplinary section, seriously undermining its impartiality. ${ }^{93}$ Second, the consensus among 'correnti' represented in the disciplinary section favored loose

\footnotetext{
${ }^{86}$ Article 17 of the law on the CSM.

${ }^{87}$ In this decision, the rule of in camera hearings and the diminished role of the advocate were at stake, among other matters; notwithstanding its clear position, the Court considered these two constitutional questions unfounded.

${ }^{88}$ Article 1 of law 74/1990, which maintains the possibility of exceptions.

${ }^{89}$ This decree was adopted before the Constitution and envisaged a disciplinary court and disciplinary tribunals, jurisdictional in character, thus reforming the previous system based on a politico-bureaucratic understanding of disciplinary responsibility, Vietti, supra note 84, at 52.

${ }^{90}$ The Constitutional Court, however, upheld this provision, despite its vagueness: see judgment of 8 June 1981, n. 100.

${ }^{91}$ Zanon \& Biondi, supra note 20 , at 282.

${ }^{92}$ The plenary of the CSM also contributed to define disciplinary offences by resorting to its 'para-normative' powers.

${ }^{93}$ Vietti, supra note 84 , at 54 et seq.. Hence, while the disciplinary system is no longer based on the old bureaucratic approach, many commentators have underlined its practical shortcomings, Zanon \& Biondi, supra note 20 , at 328 .
} 
definitions of disciplinary offenses, making the system ineffective and causing disciplinary responsibility to go underused.

In reaction, the Italian Parliament somewhat formalized the definitions of disciplinary offenses in 2005 and 2006. It is noteworthy that this was also the consequence of a 2001 ECtHR decision, which criticized the lack of foreseeability of disciplinary offenses. ${ }^{94}$ The law also increased the MJ's powers for the procedures in disciplinary investigations and indictments. ${ }^{95}$ In turn, it addressed the 'juridicisation' of disciplinary procedure, regarding the right to defense and the public viewing of hearings, canceling all traces of a typical bureaucratic form of jurisdiction. ${ }^{96}$

Reform in 2006 had a seemingly limited impact though. ${ }^{97}$ A bureaucratic approach still prevails in inspections and supervision activities, and sanctioning formal faults supposedly fosters among magistrates an approach to the judicial work that is not favorable to substantive quality. Magistrates of the General Prosecutor's office conduct the investigations and act as prosecutors in front of the Disciplinary Commission. Generally, magistrates seconded to the General Inspectorate of the Ministry also perform investigation activities. In this respect, disciplinary responsibility mostly manifests in its internal dimension.

This is confirmed by the practice. A glance at the quantitative dimension shows that the majority of disciplinary actions are taken by the General Prosecutor ${ }^{98}$. It is worth stressing that between 2007 and 2016, more than 1400 presumed disciplinary offenses on average per year have been reported to the General Prosecutor, who initiated the procedure in less than $8 \%$ of the cases. Sanctions have been imposed in slightly more than $25 \%$ of the initiated cases, mostly relating to delays. Only $4 \%$ sanctions have been of a certain

\footnotetext{
${ }^{94}$ ECtHR 2 August 2001, case no. 37119/97 N.F. v. Italy. Article 1(1) and 2(6-7) of Law no. 150/2005 and Articles 2, 3 and 4 of Legislative decree $n$. 109/2006 introduced three categories of disciplinary offences depending on whether they have been committed during or outside the exercise of the judicial functions and whether they result from committing a crime.

${ }^{95}$ See notably Article 2(6) of Law no. 150/2005 and Articles 1-4, 14, and 17 of Legislative Decree n. 106/2006.

${ }^{96}$ Zanon \& Biondi, supra note 20, at 317-321; Giuliani \& Picardi, supra note 47, at 149. 'Legalisation' of accountability implies the reliance on stricter legal standards, Kosař, supra note 2, at 38.

${ }^{97}$ Castelli, supra note 82. Data show that between 2008 and 2012 on average 150 disciplinary proceedings have been initiated each year, $25 \%$ on the initiative of the MJ and a large share in relation to delays. Disciplinary sanctions are imposed in slightly more than $10 \%$ of the cases.

${ }^{98}$ Between 2008 and 2012 31\% of disciplinary proceedings on average (50 per year on a total of 157) were instigated by the Ministry. Claudio Castelli, Un sistema disciplinare da correggere, liberiamo i magistrati dalla paura, QUESTIONE GIUSTIZIA (2013).
} 
gravity. ${ }^{99}$ For instance, in 2016 there were 156 disciplinary actions on 1,363 reported offenses, leading to 51 sanctions. Only three of those entailed the highest sanction, i.e. removal from office, and only three the second most harmful, loss of seniority. To be fair, there is disagreement on how to interpret these features. For some commentators, a limited number of sanctions indicates a working system that prevents disciplinary offenses while the high features of initiated procedures - partly on the initiative of the MJ - witness continuous disciplinary supervision. For some others, the features are rather satisfying, while the problem mostly lies in the fact that disciplinary proceedings make up for the deficiencies of other types of accountability, such as professional assessment and civil liability. ${ }^{100}$

\section{Judicial Accountability Towards the Public and the Recent Commitment to Greater Openness and Transparency}

Openness and transparency are important in favoring effective accountability to different audiences. Compared to ministerial structures, the CSM - a mixed body, where the judiciary and the civil society are represented in a pluralist manner and whose activity is public - inherently favors overt discussion and ensures a certain porosity of the judicial machinery to the outer societal environment. ${ }^{101}$ The creation of a collegiate body also cements the idea of elevating the accountability framework. This indicates that cognitively framing the CSM in terms of independence conceals one of the CSM main virtues and reasons for its establishment, i.e. the ability to reflect optimal accountability rationales. Besides this, other devices that broadly relate to JSG are also important to secure openness and transparency. In the opening ceremonies of the judicial year, court presidents publicly address problems of the judiciary that are widely publicized by the media. $^{102}$

While openness potentially and actually favored by JSG bodies cannot be refuted, corporatist logics did not go in the same direction. This is particularly true in the area of

\footnotetext{
99 Procura Generale della Corte Suprema di Cassazione, Statistiche relative all'attività della Procura generale in materia disciplinare, https://www.csm.it/documents/21768/2100643/intervento+procuratore+generale+inaugur azione+anno+giudiziario+2017+seconda+parte.pdf/4a374305-a855-3990-1eb4-c1a32d2971de; Procura Generale della Corte Suprema di Cassazione, Statistiche relative all'attività della Procura Generale in materia disciplinare http://www.cortedicassazione.it/cassazioneresources/resources/cms/documents/Relazione_statistica_proc_gen. pdf. See also SERGIO DI AMATO, LA RESPONSABILITÀ DISCIPLINARE DEI MAGISTRATI: GLI ILLECITI, LE SANZIONI (2013).

100 Nicolò Zanon, 'Sei gradi di separazione': ovvero come assicurare la terzietà della sezione disciplinare del Consiglio superiore della magistratura, RIVISTA AIC 1 (2012).

101 These general considerations may be further strengthened by the existence of powers able to enrich the quality of debate and provide more elaborate information on the state of justice, such as Article 10 opinions. Since 1970, the CSM also publishes reports on the state of justice.

${ }^{102}$ See for example http://www.cortedicassazione.it/corte-di-cassazione/it/inaugurazioni_anno_giudiziario.page.
} 
appointments that, as mentioned supra, follow informal secret agreements among 'correnti'. ${ }^{103}$ Criticism sparked initiatives to make calls and appointment procedures more transparent, especially those of court presidents. ${ }^{104}$ In the name of transparency, the CSM new internal rules of procedures approved in 2016 allowed for the publicity of meetings in which court presidents are selected; indeed, normally CSM committee meetings differently from plenary sessions of the CSM that are also regularly recorded and transmitted on the website of Radio radicale - are otherwise not public. The same rules of procedure also forbid appointments en bloc of magistrates belonging to the same court. They also generally provide that CSM activities must abide by the principles of clarity and simplicity.

The CSM's recent commitment to greater transparency, rationality, and simplification is commendable. ${ }^{105}$ Other good examples are worth mentioning, such as the disclosure regime introduced for authorizations to extra-judicial appointments of judges and prosecutors. ${ }^{106}$ Very recently, a new and more functional website has been designed to enhance the quality and quantity of activities. ${ }^{107}$ However, the picture is made of lights and shades. For example, compared to French CSM, information for judges and legal professionals as well as for citizens that would facilitate the understanding of the CSM's accessibility to information on disciplinary procedures is still not satisfactory. In conceptual terms, major concerns regard the findability (accessibility) of the data, rather than their availability. For example, information on disciplinary proceedings is provided in CSM reports; however, no complete and constantly up to date information is collected on the website. This relates more broadly to the insufficiency of statistics and relevant documents on the CSM website - striking if compared with the French CSM and the difference in available resources between the two bodies.

Notwithstanding the important steps towards greater openness, they are hardly due to virtues of the JSG regime, rather than to external pressures. First, the transparency mantra is more general and goes with the problems of courts' informatization and efficiency concerns put forth by Governments and Ministers of Justice in the last years, and by the European Commission as well. The Parliament itself justified on this basis in 2006 the opening of judicial boards to lawyers in the area of court organization and management.

\footnotetext{
103 In a recent book, a former member of the Council (a judge) reported the existence of a confidential record of the secretariat accessible only to councillors, which includes clear evidence of such informal agreements.

104 In 2011, a CSM decision also ensured greater publicity of appointment procedures. Yet, information is only accessible to judges and prosecutors through an intranet, decision of $1^{\text {st }}$ June 2011.

${ }^{105}$ Grasso, supra note 82.

${ }^{106}$ Grasso, supra note 82

107 While it should include statistics shared with the Ministry of Justice and disciplinary jurisprudence, these contents still wait to be updated, and no English version of the website is foreseen.
} 
Second, enhanced transparency of the appointment process and especially of court presidents is possibly the consequence of the encroachment of the administrative judge on the CSM's decisions. These can be indeed appealed to the Rome Administrative Court (TAR Lazio) and then to the Council of State. The practice is relevant since it defines a balance between the discretional powers of the CSM as a constitutional body and the constitutional provisions providing legal redress for acts of the public administration. ${ }^{108}$ Whatever the right balance might be, appeal is only possible on legality grounds, with the exclusion of the merits of the CSM decision itself. Nonetheless, the administrative judge traditionally went beyond legality grounds and took into consideration substantive criteria in its decisions. The review performed by the administrative judge is considered too intrusive. Thus, in the last eight years, around 30\% of the CSM's decisions on appointments of the most important positions as president and vice-president have been challenged, and $4 \%$ of these decisions have been reversed by the Rome Administrative Court. ${ }^{109}$

\section{Merits and Limits of an Italian Export Model}

This paper mapped the Italian model of JSG and discussed its impact on the independence and accountability of the judiciary. The Italian model contributed decisively to securing the independence of the judiciary in a post-authoritarian country, in which - especially during the twenty-year-long fascist dictatorship but also, to a lesser extent, in the preceding liberal period - the judiciary had been strongly dependent on the MJ. However, this independence was not achieved immediately but has been the result of a long path in which other institutional actors have also played an important part. Furthermore, the success of the Italian model of JSG varies according to values that are taken into consideration. While the independence from the executive power can be rightly considered an established achievement, the internal independence of the judiciary should rather be considered as still in the making. Similarly, while securing the independence of the judiciary, the Italian model of JSG has been far less effective in making the judiciary accountable, which in turn may have affected professionalism and diminished public confidence.

As far as external independence is concerned, it must be recalled that it was not until 1963 - i.e. 15 years after the entry into force of the new Constitution - that the appointment of judges was definitively freed from the influence of the MJ. Interestingly enough, this was

\footnotetext{
${ }^{108}$ Article 24(1) of the Italian Constitution: "Anyone may bring cases before a court of law in order to protect their rights under civil and administrative law"; Article 113(1) of the Italian Constitution: "The judicial safeguarding of rights and legitimate interests before the bodies of ordinary or administrative justice is always permitted against acts of the public administration." As mentioned in Section B., however, the Italian legal scholarship does not agree on considering the CSM, which is a constitutional body, as part of the public administration.

${ }^{109}$ CSM, Ufficio statistico - Conferimento delle funzioni direttive e semidirettive (V Commissione), September 2017, 11-15, https://www.csm.it/documents/21768/137951/Conferimenti+set+2017/bdb9ac90-4c97-f683-2d8d029 eed28b185.
} 
due to a judgment of the Constitutional Court. On the one hand, this proves the effectiveness of constitutional provisions on JSG, when they are backed by a constitutional court that is willing to take judicial independence seriously. On the other hand, this testifies that a situation of de facto (and also de jure) lack of full independence can persist for a significantly long time despite clear constitutional provisions protecting judicial independence.

The path to internal independence has been even longer, and it is still not concluded. As the figures have shown, it was only in 1981 that the artificial predominance of the judges from the Supreme Court in the CSM was redressed. Yet, the overcoming of the undue influence of the senior judges has not been followed by judicial internal independence, but rather by the influence of the 'correnti'. So far, no legislative reform has been able to properly curb this influence. However, other threats to judicial internal independence could have been properly resisted. The constitutional choice to centralize all substantive powers concerning both the careers and the disciplinary responsibility of the judges in the hands of the CSM has proven to be particularly effective. This prevented other actors, notably the courts' presidents, from exercising undue pressure over the judges, as it has happened in other jurisdictions that have adopted a similar Council of the Judiciary. ${ }^{110}$

The overall picture is far less bright as far as judicial accountability is concerned. A progression system based essentially on seniority rather than merit and a too restrained exercise of disciplinary responsibility have failed to establish a system of rewards and sanctions to make judges accountable for their behavior. To a certain extent, weak accountability seems to be the other side of the coin of a rather strong judicial independence. However, it would not be correct to claim that the Italian model of JSG is structurally unbalanced to the benefit of independence and to the detriment of accountability. The reasons for such unbalance are cultural rather than institutional. After all, as the Constitutional Court stressed in judgment 168/1963, 'the independence of the judiciary has its first and fundamental guarantee in the sense of duty of magistrates and in their obedience to the moral law, which pertains to their high office and which consists in giving justice impartially'. ${ }^{111}$ The same applies to accountability. What makes accountability difficult is not the legal framework of the Italian JSG but the corporative culture within the judiciary, which no legislative reform has been able to overcome so far. In this regard, two crucial issues stand. The first and most important, which remains outside the limited scope of this article, is the recruitment and selection procedures of new magistrates. The second concerns the initial and continuous training of judges, where the establishment of an

\footnotetext{
110 Adam Blisa \& David Kosař, Court Presidents: The Missing Piece in the Puzzle of Judicial Governance, in this issue.

${ }^{111}$ Supra note 26 , translation by the authors.
} 
autonomous judicial school seizing the powers of the CSM is supposed to open up the judiciary, even though the practical implementation still awaits proper assessment. ${ }^{112}$

${ }^{112}$ It has been observed that the transfer of powers in the field of training from the CSM to the autonomous High School for the Judiciary involved two effects: the weakening of practical, in-court training on one hand, and the "technicization" of knowledge coupled with the detachment of trainees, especially the new ones, from the main self-governing authority, on the other. 
